\title{
ANALYSIS OF FEASIBILITY STUDY OF NLI PROJECT BASED ON THE FLUCTUATION IN THE REPTILE HOBBY INDUSTRY
}

\author{
Lienardo Harvey*, Gumanti Tatang Ary \\ Graduate Program in Management, Ciputra University, Surabaya, Indonesia \\ *E-mail: skeithlee.hl@gmail.com \\ ORCID: 0000-0003-0428-5499
}

\begin{abstract}
Recently, the development of reptile hobbyists in Indonesia and the world continues to grow. The high market demand for reptile both at home country and abroad certainly shows how beneficial the reptile industry is. This research aimed to find out and analyze (1) the financial feasibility of the NLI Project based on fluctuation in the reptile hobby industry, (2) the composition of an optimal sales plan based on the financial feasibility test of the NLI Project. This research applied a quantitative descriptive approach based on a case study in the NLI Project. In this research, the authors used 3 main product lines of the NLI Project as product sampling used in the investment feasibility analysis of the NLI Project with a projection of the next 5 years. This research applied Discounted Cash Flow (DCF) method, such as Net Present Value (NPV), Internal Rate of Return (IRR), and Profitability Index (PI). The fluctuation in the reptile hobby industry was one of the main aspects in this research. Based on the results of various compositions through 19 different combinations, it could be seen that the NLI Project was feasible to run as a financial investment based on fluctuation in the reptile hobby industry. In addition, the optimal composition of sales allocation in the NLI Project was at $45-55 \%$ in the local reseller market, $35-45 \%$ in the export market, and $10 \%$ in the end-user market.
\end{abstract}

\section{KEY WORDS}

Reptile, feasibility, investment, fluctuation, industry, hobby.

Indonesia has abundant reptile diversity. Based on the collection of herpetofauna from various regions in Indonesia which are stored in the Bogor Zoological Museum, it was found that Indonesia has around 1,500 types of reptiles (Tjakrawidjaja, 2010). One family of reptile is monitor lizards. Indonesia has the most monitor lizard species in the world with a variety of patterns and colors (Bennet, 2015).

Various types of reptile in Indonesia have made a commodity for this animal, both for to be kept as pet and utilized its skin and meat. According to Mardiastuti and Soehartono (2002), the international trade of reptile as pets has been started since 1980. In 1999, as many as 161 living reptile species were recorded for sale. In September 2010 and April 2011, research on reptile traders in Maluku, West Papua and Papua provinces was conducted. Some of the most traded species are frilled lizards (Clamydosaurus kingii), bluetongued lizards (Tiliqua scincoides), and several species of monitor lizards (Varanus spp.) (Natusch and Lyons, 2011).

By with the increasing trend in reptile hobbies, the rate of monitor lizard exploitation in nature also increases dramatically. Varanus salvator is a species of monitor lizard that is spread almost throughout the Indonesian archipelago. However, this species gets less attention by the government. Smith (2013) from redOrbit.com thought that the exploitation of Varanus salvator is less noticed and leads to dangerous number of exploitation. Exploitation for the skin reaches 450,000 per year which does not include the exploitation for the meat by local residents and exploitation for keeping them as pets. Koch et al. (2013) reported that there were 6,214,310 salvator skins and 58,489 live salvators were exported in 2001-2010. Data from Nijman (2015) showed that there are at least 12,500 lizards exploited for its meat in 1 year. In addition, the findings of research conducted by Bennett (2015) reported that exploitation to the Prasinus complex in 2003-2012, especially the Varanus macraei (Prasinus 
complex) species from Batanta Island, was exploited as much as 2,847. This high rate of exploitation may result in the extinction of the monitor lizards in nature due to the minimal breeding efforts.

The monitor lizard breeding has a fairly high level of difficulty and takes a long time (Dwyer and Perez, 2007). That is because the size of the monitor lizard can grow large to the length of 1.5 meters to 2.5 meters. On average, monitor lizards reached their adulthood and can reproduce from 1.5 years age in females. Meanwhile, the males have a faster growth. An adult female monitor lizard with large size (more than 1.5 meters), is able to produce up to 40 eggs in 1 year which is divided into 2 to 3 clutch periods. Patience will be tested during the incubation period where monitor lizard eggs need 180 to 230 days for incubation until they hatch into small monitor lizards (wikipedia.en). The level of difficulty in maintaining monitor lizards and high stress level makes this reptile not easy to breed. Up to now, there are very few breeders who have succeeded breeding the monitor lizard (Fischer, 2012).

The NLI Project (Nyambek Lokal Indonesia) is a start-up business engaged in breeding the reptiles, especially lizards or nyambek (in Indonesian local Javanese) which will then be sold as exotic pets. The business started from a small scale farm on the front yard of a residence in Surabaya since May 2015 using 4 cages and 4 lizards. Then, after routinely producing and being established as monitor lizard breeding, the NLI Project expanded to a larger farm by utilizing 1 special house for monitor lizard breeding in Gresik in October 2016. On this new farm, the NLI Project had 9 large cages used for production containing 5 productive females and 4 productive males. In addition, there were 16 small cages to accommodate the production of baby monitor lizards before being sold. Up to now, the NLI Project has succeeded in hatching more than 50 lizards per year, and had a total turnover of up to 20 million rupiah in 2017.

As a company that breeds monitor lizards, the NLI Project must consider financial aspects as one of the important elements in the company especially in facing the fluctuation in the reptile industry. The NLI Project must be able to properly regulate the type of monitor lizards they produce so that their sustainability and stability can be maintained and they still have good prospects. Therefore, a feasibility analysis is required by considering the elements of fluctuation in the reptile hobby industry, the level of difficulty of production and the availability of products in the market to be able to see the potential for the future and develop appropriate production strategies.

This research aimed to analyze financial feasibility and determine the optimal composition of sales plans from the NLI Project. The results of the analysis showed that it was financially feasible to conduct an analysis on the NLI Project based on the analysis of Net Present Value, Internal Rate of Return, and Profitability Index. The analysis also showed that the optimal composition of the sales plan was in the condition of $45-55 \%$ in the local reseller market, $35-45 \%$ in the export market, and $10 \%$ in the end-user market.

NLI Project. NLI Project (Nyambek Lokal Indonesia) is a business that focused in breeding reptiles especially monitor lizards or in Javanese called nyambek. NLI Project's vision is to become a conservative based company for monitor lizards farm in Indonesia with the best care to meet the needs of reptile hobbyists in Indonesia. The NLI Project focuses on producing Indonesian local monitor lizard through the Captive Breeding (CB) method to meet the needs of the hobby market both local and international markets. The NLI Project studies the behavior and characteristic of each monitor lizard in Indonesia and breed them in captivity with proper husbandry. The NLI Project also participates in maintaining the local monitor lizard population in nature with the principle of only selling monitor lizards from the captive breeding and release programs to increase the population of monitor lizards in nature, especially the protected species. In addition, the NLI Project also provides socialization and education to hobbyists and public people about the role of monitor lizards in the balance of the ecosystem and shows that monitor lizards can be kept as a pets that are friendly to humans.

The strength point of NLI Project is to produce high-quality monitor lizards that suitable with the hobbyists need and provide good services and information. The provided quality includes attractive colors and patterns, stable health endurance, low stress levels, as well as 
the temperament of the monitor lizards that are friendly to humans. The farm area provides adequate facilities, fast customer service, and up-to-date information which make NLI Project a company that can be trusted and known by many hobbyists, both local and international. It is also supported by affordable prices for the international markets.

The NLI Project provides sellers opportunities in local and international markets to be able to sell the local Indonesian lizards with CB labels at competitive prices and high profit margins through $\mathrm{NLI}$ associates. NLI associates are a seller's cooperative relationship with NLI Project as an official store that sells CB lizards from the NLI Project. This method helps the NLI Project to distribute its products quickly and widely. Currently, there are only two NLI associates stores in Surabaya, namely Alvi Extreme Pets Indonesia (AEXPI) and Fable Pet Gallery. The future NLI Project market target will focus more on export markets and resellers compared to selling directly to the end users at a ratio of 90:10.

As a start-up business, the NLI Project is quite selective in choosing specimens that are bred due to limited land. Therefore, the NLI Project needs to take into account the number of parent assets they have and the species and morph for the breeding projects they run. It is required so that the NLI Project can maintain its business continuity and get maximum profit by utilizing their assets effectively and efficiently.

The majority of NLI Project operational costs are in the production process as monitor lizards. These costs include cage assets, parent assets, accessory requirements in cages, feed costs for monitor lizards, water, electricity, and so on. Currently, the NLI Project has not hired employees as a consideration to reduce operating costs as long as the NLI Project is still not really effective to have the income they expect. Therefore, in this development phase, the NLI Project began to take into account investment in species of monitor lizards that have more value in the reptile industry.

\section{METHODS OF RESEARCH}

The supporting data used were the data from the experts from all over Indonesia and the reptile hobbyists especially monitor lizards in Indonesia. The research was conducted for 8 months, from August 2017 to April 2018. The method used to analyze the feasibility of the NLI Project followed the basic method of capital budgeting theory. The method used was Discounted Cash Flow (DCF) method consisting of Net Present Value (NPV), Internal Rate of Return (IRR), and Profitability Index (PI) by measuring the cash flow condition for the next 5 years. An indicator that shows that the NLI Project is feasible to run is when the NPV value is $>0$, with an IRR $>6 \%$ and $\mathrm{PI}>1.0$.

Meanwhile, to analyze the condition of the company in fluctuating conditions, this research included the ratio of price fluctuation obtained from the secondary data as a reference for fluctuating trends in the common reptile hobby industry. If the calculation results remain in accordance with the feasibility indicator, the NLI Project is feasible to run as a business.

The optimal NLI Project sales allocation is based on the number of products produced each year. NLI Project has 3 sales allocations, namely end user markets with end user prices, reseller markets, and export markets. The biggest selling focus for the NLI Project lies in the reseller and export markets which control up to $90 \%$ of sales every year and the remaining $10 \%$ is controlled by the end user market. The analysis was carried out with the Real Option (RO) method by applying various different combinations which refer to the 2 main conditions, namely the biggest selling conditions in the reseller market and the biggest selling conditions in the export market. The research was conducted by using the DCF method which expects the target composition to obtain NPV $>0, I R R>6 \%$, and PI more than 1.0 .

\section{RESULTS OF STUDY}

Feasibility Test of the NLI Project without Fluctuation in Reptile Industry. The calculation trial of the feasibility test to the NLI Project was carried out in several different 
sales conditions, namely sales at end-user prices, sales at reseller prices, and sales at export prices with conditions without the influence of price fluctuation in the reptile industry.

Table 1 - Feasibility Test of the NLI Project (Annual Base; Value uses rupiah with export price and employee salary without fluctuation)

\begin{tabular}{|c|c|c|c|c|c|c|c|c|}
\hline & $\mathrm{n} / \mathrm{n}$ & \multicolumn{2}{|l|}{ Year } & 1 & 2 & 3 & 4 & 5 \\
\hline & Quantity (Lizard) (10\% increase in production every year) & \multicolumn{2}{|l|}{ Price (rupiah) } & 30 & 33 & 36 & 40 & 44 \\
\hline 1 & High Yellow Salvator (HYS) & \multicolumn{2}{|l|}{337,500} & $10,125,000$ & $11,137,500$ & $12,251,250$ & $13,476,375$ & $14,824,013$ \\
\hline 2 & Cost of Production (HYS) & \multicolumn{2}{|l|}{152,000} & $4,560,000$ & $5,016,000$ & $5,517,600$ & $6,069,360$ & $6,676,296$ \\
\hline & Quantity (Lizard) ( $10 \%$ increase in production every year) & & 20 & 22 & 24 & 27 & 29 \\
\hline 4 & Cost of Production (BD) & 322,500 & $\begin{array}{l}\frac{7,000,000}{322,500} \\
\end{array}$ & $6,450,000$ & $7,095,000$ & $7,804,500$ & $8,584,950$ & $9,443,445$ \\
\hline & Quantity (Lizard) ( $5 \%$ increase in production every year) & & & 15 & 16 & 17 & 17 & 18 \\
\hline 5 & Blue Tree Monitor (BTM) & \multicolumn{2}{|l|}{$3,500,000$} & $52,500,000$ & $55,125,000$ & $57,881,250$ & $60,775,313$ & $63,814,078$ \\
\hline 6 & Cost of Production (BTM) & \multicolumn{2}{|l|}{245,000} & $3,675,000$ & $3,858,750$ & $4,051,688$ & $4,254,272$ & $4,466,985$ \\
\hline$\overline{7}$ & Gross profit & & & $187,940,000$ & $204,292,750$ & $222,158,713$ & $241,683,106$ & $263,025,364$ \\
\hline 8 & $\begin{array}{l}\text { Operation expenses } \\
\text { Average annual inflation ratio (5.5\%) }\end{array}$ & & Qty & & & & & \\
\hline & $\begin{array}{l}\text { Expenditures for parent feed (HYS\&BD) } \\
\text { Expenditures for parent feed (BTM) } \\
\text { Annual electricity costs } \\
\text { Water fee } \\
\text { Personal salary } \\
\text { Employee salary (Assumption of the total salary is } 2.5 \text { million / month) } \\
\text { Telephone and internet fees } \\
\text { Maintenance cost } \\
\text { Transportation cost } \\
\text { ATL promotion fee } \\
\text { Exhibition operational cost } \\
\text { Farm house depreciation cost (5 years) } \\
\text { Cage depreciation cost } \\
\text { Vehicle depreciation cost } \\
\text { Depreciation costs of office equipment }\end{array}$ & $\begin{array}{l}240,000 \\
120,000 \\
3,600,000 \\
1,020,000 \\
24,000,000 \\
30,000,000 \\
2,400,000 \\
6,000,000 \\
7,200,000 \\
3,600,000 \\
2,500,000 \\
2,147,400 \\
5,270,004 \\
5,004,000 \\
1,020,600\end{array}$ & $\begin{array}{l}9 \\
9 \\
1 \\
1 \\
1 \\
1 \\
1 \\
1 \\
1 \\
1 \\
5 \\
1 \\
1 \\
1 \\
1\end{array}$ & $\begin{array}{l}2,160,000 \\
1,080,000 \\
3,600,000 \\
1,020,000 \\
24,000,000 \\
30,000,000 \\
2,400,000 \\
6,000,000 \\
7,200,000 \\
3,600,000 \\
12,500,000 \\
2,147,400 \\
5,270,004 \\
5,004,000 \\
1,020,600\end{array}$ & $\begin{array}{l}2,278,800 \\
1,139,400 \\
3,798,000 \\
1,076,100 \\
25,320,000 \\
31,650,000 \\
2,532,000 \\
6,330,000 \\
7,596,000 \\
3,798,000 \\
13,187,500 \\
2,147,400 \\
5,270,004 \\
5,004,000 \\
1,020,600\end{array}$ & $\begin{array}{l}2,404,134 \\
1,202,067 \\
4,006,890 \\
1,135,286 \\
26,712,600 \\
33,390,750 \\
2,671,260 \\
6,678,150 \\
8,013,780 \\
4,006,890 \\
13,912,813 \\
2,147,400 \\
5,270,004 \\
5,004,000 \\
1,020,600\end{array}$ & $\begin{array}{l}2,536,361 \\
1,268,181 \\
4,227,269 \\
1,197,726 \\
28,181,793 \\
35,227,241 \\
2,818,179 \\
7,045,448 \\
8,454,538 \\
4,227,269 \\
14,678,017 \\
2,147,400 \\
5,270,004 \\
5,004,000 \\
1,020,600\end{array}$ & $\begin{array}{l}2,675,861 \\
1,337,931 \\
4,459,769 \\
1,263,601 \\
29,731,792 \\
37,164,740 \\
2,973,179 \\
7,432,948 \\
8,919,537 \\
4,459,769 \\
15,485,308 \\
2,147,400 \\
5,270,004 \\
5,004,000 \\
1,020,600\end{array}$ \\
\hline & Total operating expenses & & & $107,002.004$ & $112,147,804$ & $117,576,623$ & $123,304,027$ & $129,346,438$ \\
\hline $\begin{array}{l}9 \\
10 \\
11 \\
12\end{array}$ & $\begin{array}{l}\text { Operating profit } \\
\text { Interest expenses } \\
\text { Profit before tax } \\
\text { Tax (30\% of profit available) }\end{array}$ & & & $\begin{array}{l}80,937,996 \\
0 \\
80,937,996 \\
24,281,399\end{array}$ & $\begin{array}{l}92,144,946 \\
0 \\
92,144,946 \\
27,643,484\end{array}$ & $\begin{array}{l}104,582,090 \\
0 \\
104,582,090 \\
31,374,627\end{array}$ & $\begin{array}{l}118,379,079 \\
0 \\
118,379,079 \\
35,513,724\end{array}$ & $\begin{array}{l}133,678,926 \\
0 \\
133,678,926 \\
40,103,678\end{array}$ \\
\hline 13 & Profit after tax & & & $56,656,597$ & $64,501,462$ & $73,207,463$ & $82,865,355$ & $93,575,248$ \\
\hline & $\begin{array}{l}\text { Depreciation } \\
\text { Present Value of Investment (B) } \\
\text { Discount Factor } 6 \% \\
\text { Present Value of Proceeds (A) }\end{array}$ & $\begin{array}{l}-158,150,500 \\
398,696,330\end{array}$ & & $\begin{array}{l}13,442,004 \\
70,098.601 \\
0.9708 \\
68,051,722 \\
\end{array}$ & $\begin{array}{l}13,442,004 \\
77,943.466 \\
0.9426 \\
73,469,511 \\
\end{array}$ & $\begin{array}{l}13,442,004 \\
86,649,467 \\
0.9151 \\
79,292,927 \\
\end{array}$ & $\begin{array}{l}13,442,004 \\
96,307,359 \\
0.8885 \\
85,569,088 \\
\end{array}$ & $\begin{array}{l}13,442,004 \\
107,017,252 \\
0.8626 \\
92,313,082 \\
\end{array}$ \\
\hline & $\begin{array}{l}\text { Net Present Value }(A)-(B) \\
\text { The IRR generates value of } \\
\text { Profitability Index }\end{array}$ & $\begin{array}{l}240,545,830 \\
42.84 \% \\
2.52\end{array}$ & & & & & & \\
\hline
\end{tabular}

This initial experiment was carried out with the current NLI Project adaptation, which was without the employee's salary and only included the personal salary of the NLI Project owner. In addition, in the development of a business, one of the main elements is the existence of competent employees who can keep the company running smoothly in which it helps the owner in running the company. Therefore, the experiment was also carried out by adding employee salaries to the monthly operational costs of the NLI Project.

Table 1 below illustrates the basic basis used in the calculation process of the feasibility test to the NLI Project. Table 1 shows that the initial investment value of the NLI project was IDR $158,150,500$. All of the money comes from the private fund of the owner. The fund value is a reference in the investment feasibility assessment.

Using the same base as in Table 1, the trial of six combinations was carried out. The two main conditions used were conditions without employees and conditions with employees, each of which had three different prices based on the target market, namely end-user price, reseller price, and export price.

Table 2 - Feasibility Test of the NLI Project without Fluctuation (5-year base)

\begin{tabular}{|c|c|c|c|c|c|c|}
\hline \multicolumn{6}{|c|}{ Investment Value: IDR $158,150,500$} & \multirow{2}{*}{$\begin{array}{l}\text { Without Fluctuation } \\
\text { Conclusion }\end{array}$} \\
\hline No & Conditions & NPV & & IRR & $\mathrm{Pl}$ & \\
\hline \multicolumn{7}{|c|}{ Without employee salary } \\
\hline $\begin{array}{l}1 \\
2 \\
3 \\
\end{array}$ & $\begin{array}{l}\text { End-user price } \\
\text { Reseller price } \\
\text { Export price }\end{array}$ & $\begin{array}{l}\text { IDR } \\
\text { IDR } \\
\text { IDR } \\
\end{array}$ & $\begin{array}{l}561,964,279 \\
376,261,302 \\
347,555,442 \\
\end{array}$ & $\begin{array}{l}86.26 \% \\
62.04 \% \\
58.18 \% \\
\end{array}$ & $\begin{array}{l}4.55 \\
3.38 \\
3.20 \\
\end{array}$ & $\begin{array}{l}\text { Feasible } \\
\text { Feasible } \\
\text { Feasible }\end{array}$ \\
\hline \multicolumn{7}{|c|}{ With employee salary } \\
\hline $\begin{array}{l}4 \\
5 \\
6\end{array}$ & $\begin{array}{l}\text { End-user price } \\
\text { Reseller price } \\
\text { Export price }\end{array}$ & $\begin{array}{l}\text { IDR } \\
\text { IDR } \\
\text { IDR }\end{array}$ & $\begin{array}{l}454,954,668 \\
269,251,690 \\
240,545,830\end{array}$ & $\begin{array}{l}72.05 \% \\
46.92 \% \\
42.84 \%\end{array}$ & $\begin{array}{l}3.88 \\
2.70 \\
2.52\end{array}$ & $\begin{array}{l}\text { Feasible } \\
\text { Feasible } \\
\text { Feasible }\end{array}$ \\
\hline
\end{tabular}


Based on the simulation of feasibility test in Table 2, the NLI Project was considered as $100 \%$ feasible to run as a business with the conditions without fluctuations. The feasibility indicator could be seen in the NPV value $>0$, the IRR value $>6 \%$, and the $\mathrm{PI}$ value $>1.0$. Employee salary had an impact on decreasing profits. However, it did not affect the feasibility of the NLI Project and continued to provide significant profit increase as shown in Table 1. The amount of the NPV, IRR, and PI figures decreased slightly after the component of employee salary was included.

Feasibility Test of the NLI Project with Fluctuation in Reptile Industry. As a tertiary need for hobbies, the reptile industry is quite developed and has a broad market. However, in terms of business, the reptile industry has very high dynamics that affect price fluctuation.

The NLI Project, as one of the new businesses in the industry, needs to review the business feasibility in terms of finance by including the element of price fluctuation that occurs in the reptile industry. The price fluctuation ratio used in this simulation used the data on price fluctuation of other reptiles i.e. Iguana that were obtained from the expert sources as the owner of the largest reptile shop in Surabaya, Budi Wonosasmito.

Table 3 - Feasibility Test of the NLI Project (Annual Base; Value uses rupiah with the selling price of local resellers with employee salary and fluctuation)



Table 3 above illustrates the basic basis used in the calculation process of feasibility test of the NLI Project with fluctuations. The fluctuation ratio uses fluctuating ratio conditions on 3 types of Iguanas, namely Green Iguana, Blue Iguana, and Albino Iguana. The placement of the fluctuation ratio adjusts the price of the three types of Iguana which become the benchmark and the price of the three types of NLI Project products used in the simulation.

Based on Table 4, five of the six trials concluded that the NLI Project was feasible to run as a business. However, on the 6th experiment, with the use of employee salary and export prices, the IRR value was $4.82 \%$ in which it was below the feasibility standard of $6 \%$. It showed that the NLI Project was not feasible to run with the use of this condition. 
Table 4 - Feasibility Test of NLI Project without Fluctuation (5-year basis)

\begin{tabular}{|c|c|c|c|c|c|c|}
\hline \multicolumn{6}{|c|}{ Investment Value: IDR $158,150,500$} & With Fluctuation \\
\hline No & Conditions & $\overline{N P V}$ & & IRR & $\mathrm{PI}$ & Conclusion \\
\hline \multicolumn{7}{|c|}{ Without employee salary } \\
\hline 1 & End-user price & IDR & $268,878,314$ & $62.00 \%$ & 2.7 & Feasible \\
\hline 2 & Reseller price & IDR & $134,694,756$ & $35.56 \%$ & 1.85 & Feasible \\
\hline 3 & Export price & IDR & $115,523,180$ & $31.40 \%$ & 1.73 & Feasible \\
\hline \multicolumn{7}{|c|}{ With employee salary } \\
\hline 4 & End-user price & IDR & $161,868,703$ & $42.83 \%$ & 2.02 & Feasible \\
\hline 5 & Reseller price & IDR & $26,116,845$ & $10.90 \%$ & 1.17 & Feasible \\
\hline 6 & Export price & IDR & 5.680 .572 & $4.82 \%$ & 1.04 & Not Feasible \\
\hline
\end{tabular}

The fluctuation condition caused a significant decrease in turnover resulting in loss conditions that began to appear in the 5th year in terms of sales at reseller price and employee salary. It could be seen in the simulation example in Table 3 even though based on Table 4 number 5 it was still in the feasible category. Fluctuating conditions resulted in drastic decrease of annual profit each year with large losses in the 5th year. It showed that the condition of the company was not well developed and unable to deal with conditions of price fluctuation coupled with inflation condition on operational costs that continue to increase every year despite an increase in production by $10 \%$ annually.

Analysis of the Composition of Effective Sales Plans Based on Financial Feasibility Test on the NLI Project. In taking the future sales strategy, the NLI Project needs to determine the appropriate sales allocation in order to obtain optimal profits despite price fluctuation in the reptile industry. Therefore, the feasibility test was carried out on the NLI Project by considering the sales allocation with the condition of $10 \%$ in the local market, and the remaining $90 \%$ will be divided into two conditions, i.e. the biggest selling condition was performed at the local reseller market and on the export market using the Real Option method. This method was performed by comparing 19 different combinations of composition between local and export resellers in $90 \%$ of sales.

The results of the feasibility test on the NLI Project with 19 sales combinations indicated that the NLI Project is $100 \%$ feasible to run as a business even though using 19 different combinations of sales composition. It could be seen from the lowest NPV condition that showed a positive number. Meanwhile, the lowest IRR was $9.63 \%$. It meant that the IRR value was still above the lowest interest rate, which was $6 \%$. The lowest PI calculation also shows a ratio of 1.14 which was above the lowest ratio of 1.00 .



(a) (c)

Figure 1 - Charts of NPV (a), IRR (b), PI (c) NLI Project

Based on Figure 1(a), the highest NPV condition was IDR 40,276,088 in which $90 \%$ of the sales were allocated to local resellers and the remaining $10 \%$ was allocated to endusers. Meanwhile, the worst condition of NPV was IDR 21,865,833 in which the condition where $90 \%$ of sales was allocated to exports and the remaining $10 \%$ to end users.

In addition to NPV chart, this research also presented the IRR chart of the NLI Project. Figure 1(b) also showed the NLI Project IRR graph in various sales conditions with the highest IRR of $14.71 \%$ in which it found the condition of $90 \%$ sales allocation in the local reseller market, and $10 \%$ in the end user without an allocation to the export market. Meanwhile, the worst condition was the IRR of $9.63 \%$, in which condition where $90 \%$ of sales was allocated to exports and $10 \%$ to end users. 
Based on NPV and IRR charts, it could be predicted that similar things could occur to $\mathrm{PI}$. Based on Figure 1(c), the PI chart of the NLI Project showed that the highest profit condition was 1.25 which was in 2 conditions. The first condition lied when sales allocation is $90 \%$ at local resellers and $10 \%$ at end users without export sales. The second condition was when the sales allocation is $85 \%$ at local resellers, $10 \%$ at end users, and $5 \%$ in export markets. Meanwhile, the worst condition of PI was at 1.14 where $90 \%$ sales allocation in exports and the remaining $10 \%$ were in the end user.

Based on the results of the analysis, it was known that the best sales allocation conditions were dominated where sales allocation to local resellers at $90 \%$ and $10 \%$ sales to end users without export sales. However, in reality, export sales must still be performed. That is because the local resellers might not be able to absorb $90 \%$ of NLI Project products considering the sales to the end user was only at $10 \%$. The balance of sales allocation between local resellers market and export market is necessary to find the possible optimal sales allocation. The balanced condition from 19 different combinations was the average NPV value of IDR $30,967,422$, IRR of $12.19 \%$ and PI ratio of 1.20 . Based on that, the average condition was closest to the condition of sales allocation within $45-55 \%$ at local resellers, $10 \%$ at end users and allocating between $35-45 \%$ to export markets.

\section{DISCUSSION OF RESULTS}

Based on the analysis results on the first problem regarding the financial feasibility test, the NLI Project is considered to be more than $90 \%$ feasible to run as a business if it is viewed from the calculation results with the three DCF methods, namely NPV, IRR, and PI. This research was conducted in 2 main conditions, namely the stable price condition and the condition with price fluctuation. The price standard used in this research was based on 3 different target markets, namely end user, local reseller, and export.

The results of the feasibility test at stable prices found that the NLI Project is feasible to run as a business even with 6 different conditions and the increasing income. Different condition was found in the results of feasibility test with price fluctuation in the reptile hobby industry. In fluctuating conditions, 5 out of 6 conditions in the NLI Project were considered as feasible to run as businesses under consideration that the income continues to decline every year. The NLI Project was considered as not feasible in the 6th condition, namely in Table 4 number 6 in which 100\% of sales using export prices showed an IRR of $4.82 \%$ below the $6 \%$ interest rate and experienced losses in the 5th year.

Other analysis results were aimed at the second problem regarding the composition of an optimal sales plan based on the financial feasibility test of the NLI Project. This analysis was carried out by taking into account the existence of price fluctuations in the reptile industry by dividing sales allocations in 3 different target markets directly, namely end users, local resellers, and exports. The composition of the sales plan was based on the company's sales conditions in which the $10 \%$ were in the end user market and the remaining $90 \%$ were between the local reseller and export markets. Therefore, in this analysis there were 2 main conditions, namely the condition where the biggest sales focused on the local reseller market and the condition where the biggest sales focused on the export market.

The results of the analysis on the second problem showed that out of 19 different combinations, the NLI Project was $100 \%$ feasible to run as a business if it was referring to the results of 3 DCF analyzes, namely NPV, IRR, and PI. The highest income condition was obtained when $90 \%$ of sales were addressed to local resellers. Meanwhile, the lowest income occurred when $90 \%$ of sales were directed to exports. However, the conditions did not allow local resellers to be able to absorb $90 \%$ of the total NLI Project production if it is viewed from the average sales to the end user directly which was only $10 \%$. If it is viewed from the various possibilities that might occur, then the most ideal condition was in an average position where the composition of sales was $45-55 \%$ to local resellers, $35-45 \%$ to exports, and $10 \%$ to end users. If the NLI Project ends in an export condition that is more dominant than the local reseller, then the calculation results still support the feasibility of the 
NLI Project as a company. However, it will be better if the NLI Project is able to increase the sales to the end user because it will increase the sales significantly.

Referring to the analysis results on the first and second problems, there are several things that need attention. One of them is the condition where there was fluctuation in selling prices. The condition of selling price fluctuation that tended to decline was not balanced with an increase in production each year and it caused a significant decrease in company turnover. This condition can be fatal and cause losses to the company. This is shown in Table 4 number 6 where the NLI Project is considered as not feasible to run as a business because the IRR is below the minimum interest rate limit. In addition, the condition of the company experienced losses in the 5th year. The condition of losses in the 5th year was also experienced in several other conditions of feasibility tests, one of which is shown in Table 3 and also occurred in all analysis calculations of the 2 nd research problem regarding the composition of an effective sales plan.

The findings of this research are relatively consistent with previous research under several notes. This research is appropriate to be used as a method of investment feasibility analysis because it applied the NPV, IRR and PI methods. The DCF method has been used in $61.4 \%$ of companies in Indonesia as a company feasibility analysis (Leon and Kester, 2008).

These research findings strengthen Swastawati's (2011) research who conducted a feasibility test analysis using NPV, IRR, and PI. The difference made in Swastawati's research is the existence of non-DCF methods such as the Payback Period (PP) which was not carried out in this research. PP is commonly used in the feasibility test analysis to find out how long the investment made by the company can return and get the profit. In this research, this condition can be seen from the calculation of NPV.

Hafidzi's (2012) research also used the same basic method, namely using NPV, IRR and Monte Carlo simulations with additional Discounted Payback Period (DPP), B/C Ratio to test the feasibility of expansion on CV Globalz Mandiri Jember. Hafidzi applied uncertainty or fluctuation conditions by applying Monte Carlo simulation to the company's cash flow in standard, optimistic and pessimistic conditions.

Based on the findings of the above research, the most expected field conditions are if the selling price can be stable without fluctuations. It is because the income continues to rise every year with high profits so that it shows very good business prospects. However, if there is a fluctuation in field conditions, there is a need for anticipation from the NLI Project to deal with these conditions.

Based on the internal factors, the above research conditions only calculated the production figures of one parent in each product line. Meanwhile, the NLI Project had 3 normal females that could increase production rates rapidly. Even so, in fluctuating conditions, the NLI Project has a significant decrease in turnover every year which can result in losses at some stage. The total number of parents will indeed increase the company's turnover, but it is possible that the decline in prices will continue to decrease the company's turnover. One solution that can be performed is to replace one of the parents of High Yellow Salvator with the Black Dragon parent. Therefore, the NLI Project will get a high profit.

Another anticipation that can be performed simultaneously with adding product lines is to expand the farm to a larger scale. However, this step will be safer to do if it has been retested financially to ensure that the expansion does not result in losses. These steps are an effort of anticipation that can be carried out internally by the company.

As a company that sells a product, it certainly needs to pay attention to external factors affecting the circulation and the prices of products sold by the NLI Project. Regarding to the conditions of fluctuations in other reptiles, fluctuating factors tend to be caused by an increase in the number of products on the market. Therefore, external factors that may cause fluctuations need to be considered. One of the external factors is the presence of competitors among breeders and the level of natural catch supplies. Because of the lizards of the NLI Project are Indonesian local lizards, it needs to be a concern because it will affect the market conditions of end users and local resellers who sell their products to end users. To overcome this condition, it would be more profitable if the NLI Project prioritizes its sales to the export 
market and maintains price stability in the local market. Therefore, the condition of price fluctuations in the local market can be minimized because the conditions of the destination countries of the export market cannot get monitor lizards in their nature.

In responding to competitor breeders, the NLI Project can conduct cooperative relationships between businesses to be able to maintain price stability so that the monitor lizard sales value can be more stable. This condition plays a good role with fellow domestic breeders, as well as the foreign breeders. Diplomatic relations with local breeders in pricing can maintain the stability of export prices because it reduces the risk of price competition. It should be realized by seeing the minimum number of monitor lizards in Indonesia. Meanwhile, diplomatic relations with foreign breeders can indirectly maintain the stability of export sales prices as well. This is due to differences in prices between natural wild caught monitor lizards and captive breed monitor lizards on international markets. Prices set by foreign breeders will affect the value of the selling price that Indonesian exporters can offer to outside importers. In addition, it may lead to the price that can be offered by the NLI Project to the export market.

Regarding to the relatively lower profit on export sales prices, the NLI Project still needs to anticipate the local market especially to maintain sales stability to local resellers which leads to end users. In facing the existence of wild caught animals that can affect the captive breeding of monitor lizards, the NLI Project needs to reconsider the advantages of the products they produce.

Good character, attractive colors and low levels of stress on captive breed monitor lizards are special advantages that are not necessarily obtained from natural catch lizards which can make price differentiation. Therefore, the conditions of circulation of wild caught monitor lizards are not entirely a threat if they are addressed in the right way. The anticipation that can be carried out is to routinely disseminate information about good captive breed monitor lizards through media promotions and exhibitions. If the hobbyists know the differences, they will prefer captive breed monitor lizards because it answers their main problems with natural catch monitor lizards in terms of adaptability, stress, disease and character. Therefore, the conditions of circulation of wild caught monitor lizards do not significantly affect price fluctuations in captive breed monitor lizards. In this case, proper promotion and communication can increase sales prospects to end users in Indonesia and of course will affect sales to local resellers.

\section{LIMITATIONS OF THE RESEARCH}

Analysis of the feasibility test on the NLI Project in this research is still far from perfection. It is because this research only prioritizes financial perspective. Meanwhile, based on the discussion in Chapter 5, the NLI Project needs to consider many other factors that will affect the conditions of calculation and assumptions of this research. The following are the limitations of this research.

- This research only applied the DCF method to measure the investment feasibility of a company;

- This study only used neutral/fixed production conditions. The existence of combination changes was only applied from price fluctuation and sales composition;

- The research did not take into account other conditions such as normal, pessimistic, and optimistic conditions for sales and production in the analysis of feasibility test.

\section{CONCLUSION AND SUGGESTIONS}

This research aimed to analyze the financial feasibility of the NLI Project. NLI Project is a company engaged in captive breeding of monitor lizards. The analytical method used in this research was based on Discounted Cash Flow (DCF), including Net Present Value (NPV), Internal Rate of Return (IRR), and Profitability Index (PI). Based on the analysis results, it could be concluded that the NLI Project is financially considered as feasible as a financial investment based on fluctuation in the reptile hobby industry. In addition, the optimal 
composition of sales allocation in the NLI Project was at $45-55 \%$ in the local reseller market, $35-45 \%$ in export market, and $10 \%$ in the end-user market.

In conducting a research, it certainly may not be a perfect research. Various aspects, both technical and non-technical, can be overlooked and become input and consideration for future research. Therefore, the following are suggestions given by the authors to the company and future research:

- The use of the DCF method is indeed feasible enough to conduct an analysis on investment feasibility test. However, it would be better if the next research could complete it with non-DCF methods such as Break Even Point (BEP) as conducted in Hadi's research (2010) or Payback Period (PP). The use of the BEP method will show clearly what the selling price needs to be maintained by the company and the amount of production that needs to be achieved to prevent losses. The use of the PP method can clearly present how quickly the issued initial investment can be returned and generate profits for the company.

- Future research can apply the Real Option (RO) method which can provide additional solutions in determining the company's strategy to complement the achieved analysis results from both DCF and non-DCF methods (Ghahremani et al., 2012). In this case, the researchers can do more analysis by trying to make compositions outside the existing limits. Next, the researcher can compare the results of the analysis with the existing boundary conditions. Thus, the research may open up the potential with wider discussion to get the best solution.

- Future research can also apply additional conditions to sales and production such as neutral, pessimistic and optimistic conditions. By using these conditions, it can be known the condition of the company beyond the assumptions made and expected in this research.

\section{REFERENCES}

1. Bennet, D. (2015) "International Trade in the Blue Tree Monitor Lizard Varanus Macraei", Biawak: International Varanid Interest Group, 9 (2), pp. 50 - 57.

2. Dwyer, Q. dan Perez, M. (2007) "Husbandry and Reproduction of the Black Water Monitor, Varanus Salvator Komaini”, Biawak: International Varanid Interest Group, 1 (1), pp. $13-20$.

3. Fischer, D. (2012) "Notes on the Husbandry and Breeding of the Black Tree Monitor Varanus (Euprepiosaurus) Beccarii (Doria, 1874)", Biawak: International Varanid Interest Group, 6 (2), pp. 79- 87

4. Hafidzi, A. H. (2012) "Analisis Fisibilitas Investasi CV. Era Globalz Mandiri Jember Pada Kondisi Ketidakpastian", Tesis, Jember: Universitas Jember.

5. Koch, A., Ziegler, T., Bohme, W., Arida, E., dan Auliya, M. (2013) "Distribution, Threats, and Conservation Status of the Monitor Lizards (Varanidae: Varanus spp.) of Southeast Asia and the Indo-Australian Archipelago", Herpetological Conservation and Biology, 8 (3), pp. 7, 22-18, 34-42.

6. Leon, F.M, dan Kester, G.W. (2008) "Capital Budgeting Practices of Listed Indonesian Companies", Asian Journal of Business and Accounting, 1 (2), pp. 175 - 192.

7. Mardiastuti, A. dan Soehartono, T. (2002) "Perdagangan Reptil Indonesia di Pasar Internasional", Indonesia: Institut Pertanian Bogor, pp. 134.

8. Natusch, D. dan Lyons, J. A. (2011) "Exploited for Pets: The Harvest and Trade of Amphibians and Reptiles from Indonesian New Guinea", Biodiversity and Conservation, 21 (8), pp. 6-8.

9. Nijman, V. (2015) "Water Monitor Lizards for Sale as Novelty Food in Java, Indonesia", Biawak: International Varanid Interest Group, 9 (1), pp. 28 - 32.

10. Smith, B. (2013) "Rate of Water Monitor Lizard Harvesting Unsustainable, Says Study", Available at: http://www.redorbit.com/

11. Tjakrawidjaja, A. H. (2010) "Studi Fauna Eksotik Ikan Air Tawar, Reptilia, dan Amphibia Asli Indonesia”, Bogor: LIPI. 